\title{
New Application in Technological Preparations for Investment Casting Production in Air- craft Industry
}

Augustín Sládek, Richard Pastirčák, Marek Brůna, Anna Remišová

Department of technological engineering, Faculty of Mechanical Engineering, University of Žilina, Univerzitná 1,010 26 Žilina, Slovakia, E-mail: augustin.sladek@fstroj.uniza.sk, richard.pastircak@fstroj.uniza.sk, marek.bruna@fstroj.uniza.sk, anna.remisova@fstroj.uniza.sk, Tel.: + 421415132772

Nowadays, foundries do not sufficiently utilizes computer support during the creation of technical documentation. Instead of computer documentation, foundries are using classical method for designing technological documentation and the computer aid is only discrete. For the area of foudry technology, it is inappropriate to use conventional CAPP systems which use group technology because they work with a simple representative selection from the database according to the characteristics. The submitted article shows a solution for systems interconnection and the possibilities of using the simultaneous engineering for aircraft industry. A new system was designed serving as the creation tools for technological documentation, whose role is to effectively benefit from group technology with use of latest software capabilities.

Keywords: CAD, CAE CAPP, turbine

\section{Acknowledgement}

This work was created within the framework of the VEGA project grant no. 1/0494/17. The authors thank the grant agency for their support.

\section{References}

[1] KUBA, J., JANČUŠOVÁ, M., MORAVEC, J.: Počítačová podpora inžinierskych prác v tvárnení a zlievarenstve. EDIS Žilina, 2006, 122 s., ISBN 80-8070-516-X

[2] KANTORÍK, R., BOLIBRUCHOVÁ, D.: Free melt surface monitoring with the help of metal flow simulation in moulds. In: International foundry research: official journal of World Foundry Organization, Vol. 63, no. 2 (2011), s. 18-23, ISSN 0046-5933

[3] EPERJEŠI, L., et al.: Influence of returning material on porosity of die castings. In: Manufacturing Technology. Vol. 13, no. 1, 2013, p. 36-39, ISSN 1213-2489

[4] BOLIBRUCHOVÁ, D.: Zlievarenská technológia, Georg Žilina, 2010, ISBN 978-80-89401- 14-7

[5] MALIK, J., FUTÁŠ, P., VASKOVÁ, I., EPERJEŠI, Š.: Vplyv technologických faktorov liatia na kvalitu odliatkov zo silumínu. Slévárenství, 2007, č. 4-5, s. 259-262, ISSN 0037-6825

[6] LENHRAD, R. - KADUCHOVÁ, K. - PAPUČÍK, Š. 2014. Analysis of the fill amount influence on the heat performance of heat pipe. XIX. the application of experimental and numerical methods in fluid mechanics and energetics 2014 : proceedings of the international conference. AIP Publishing, 2014. - ISBN 978-0-7354-1244-6. - pp. 146-152.

[7] BOLIBRUCHOVÁ, D., ŽIHALOVÁ, M. 2016. Evaluation of vanadium influence in AlSi10MgMn alloy with increased iron. Manufacturing technology, vol. 16, no. 2, pp. 471-475. ISSN 1213-2489.

[8] BOLIBRUCHOVÁ, D. RICHTÁRECH, L. 2016. Possibilities of using Al-Si-Mg alloys with higher Fe content for demanding castings. Manufacturing technology, vol. 2016, no. 2, pp. 317-323. ISSN 1213-2489.

[9] BOLIBRUCHOVÁ, D., ŽIHALOVÁ, M. 2013. Possibilities of iron elimination in aluminium alloys by vanadium. Manufacturing technology, vol. 13, no. 3, pp. 289-296. ISSN 1213-2489.

[10] BOLIBRUCHOVÁ, D. RICHTÁRECH, L. 2013. Effect of adding iron to the AlSi7Mg0.3 (EN AC 42 100, A356) alloy. Manufacturing technology, vol. 13, no. 3, pp 276-281. ISSN 1213-2489. 